\title{
THE EXPANSION OF ACTIVITY-BASED COSTING/MANAGEMENT IN THE CZECH REPUBLIC
}

\author{
Jana Pokorná
}

\begin{abstract}
This paper aims to investigate the expansion of an advanced management tool - Activitybased costing/management (ABC/M) among Czech companies and to map the level of its utilization. The empirical survey was carried out among 548 Czech medium-sized and large companies from various economic sectors. The expansion of $\mathrm{ABC} / \mathrm{M}$ has grown to $22 \%$ in 2013 which is comparable to neighbouring countries, but companies still use a relatively simple $\mathrm{ABC} / \mathrm{M}$ model. They use only a limited extent of $\mathrm{ABC} / \mathrm{M}$ and do not exploit all its possibilities.
\end{abstract}

\section{Keywords}

Activity based costing, Activity based management, the Czech Republic, cost management

\section{Introduction}

Global competitive market environment makes pressure on companies to provide quality products at affordable prices. To fulfil this task, companies are forced to seek ways to reduce costs and increase productivity. For effective cost reduction, managers must understand how firm costs are generated. In the Czech conditions, already Tomáš Bata realized the importance of cost management, who introduced an extensive cost calculation department in his company (Rybka, 2003).

An advanced management tool that helps with cost tracking is Activity based costing/management $(\mathrm{ABC} / \mathrm{M})$. It brings a process view of the firm costs, when instead of organizational departments in traditional conception, firm activities and processes generate value and costs. Managers get completely new information about activity costs and more accurate information about product or customer costs. Ways of utilisation of $\mathrm{ABC} / \mathrm{M}$ information have been many times described in academic and popular literature (e.g. Cokins, 2001).

After the origin in the late 1980s, the ABC/M expanded rapidly among large enterprises, particularly in the USA and other English-speaking countries (Majerová, 2010). In Central and Eastern Europe the expansion is slower. Previous research (Popesko and Novák, 2008) showed that it has taken a longer time to become established in Czech business practice. More extensive and recent research has not been published so the situation about ABC/M diffusion and use has not been mapped. Scope and complexity of most common use of the ABC model has not been examined.

Based on the present situation, the aim of this paper is to chart the expansion of $\mathrm{ABC} / \mathrm{M}$ amongst businesses in the Czech Republic and to ascertain how it is utilized. To reach this, it was carried out an extensive questionnaire survey among Czech businesses. Results show that recent $\mathrm{ABC} / \mathrm{M}$ expansion is comparable to neighbouring countries, but companies still use a relatively simple $\mathrm{ABC} / \mathrm{M}$ model. They use only a limited extent of $\mathrm{ABC} / \mathrm{M}$ and do not exploit all its possibilities. 


\section{$\mathrm{ABC} / \mathrm{M}$ in a literature review and its theoretical basis}

Activity based costing/management is an advanced management tool that provides more accurate information about company costs and helps in company performance measuring. What started out in the 1980s in USA as a calculation technique became a complex approach to the management of an organization's activities.

In contrast to traditional calculation method, activity based costing emphasizes process view to the company. It is not necessary in what department costs are generated, but what activities are performed in creating a final product. In calculation, resources are allocated to activities and activities are allocated to cost objects based on their use. Important is identification of causal relationship of cost drivers to activities (CAM-I, 2000). Managers can measure cost of products, customers, divisions, departments, product lines, regions, or a combination of these. Utilizing the information from activity based costing in the business management is called activity based management. In practice the border between $A B C$ and $A B M$ is not clear, that is why the term activity based costing/management is widely used.

$\mathrm{ABC} / \mathrm{M}$ provides, next to more accurate information about product costs, also new information about causes of overheads and cost of activities. This information is not available without ABC/M. According to empirical research (Cohen et al., 2005; Innes et al., 2000; Krumwiede and Suessmair, 2008), ABC/M information is widely utilized for more precise product-cost calculations and their reduction, product pricing, cost modelling, customers and products profitability management, activity cost analysis, an identification of cost factors (cost drivers), budgeting, deciding on production volume and product mix, decisions concerning outsourcing, measuring the costs of unused capacity, measurement of (insufficient) quality costs, benchmarking, re-engineering and procedural improvement.

$\mathrm{ABC} / \mathrm{M}$ information used for better decision making should improve company performance. Many studies looked for the relationship between the use of ABC and firm performance have been accomplished (e.g. Innes et al., 2000; Kennedy and Affleck-Graves, 2001; Cagwin with Barker, 2006; Krumwiede and Charles, 2011; Hardan and Shatnawi, 2013; Mijoč et al., 2014; Ayedh et al., 2015 and others). The direct impact of ABC/M on company performance has been detected rarely. Indirect influence through improving product quality and production time was examined and found by Ittner et al. (2002). Banker et al. (2008) work with the idea that the impact of $\mathrm{ABC} / \mathrm{M}$ on performance is completely indirect and affects performance only through allowing the introduction of other advanced manufacturing practices as Just-intime, Total quality management, continuous improvement and benchmarking, which have a direct positive impact on business performance. Many studies (Cagwin and Bouwman, 2002; Cagwin and Barker, 2006; Maiga and Jacobs, 2006; Al-Khadash and Feridun, 2006) discovered a synergically positive effect on company performance by using other strategic initiatives in conjunction with $\mathrm{ABC} / \mathrm{M}$.

$\mathrm{ABC} / \mathrm{M}$ brings the greatest benefits in medium-sized and large businesses, in enterprises with large product diversity and high ratio of overheads (Krumwiede, 1998; Cooper and Kaplan, 1990; Cagwin and Bouwman, 2002). Manufacturing industry is the most experienced with $\mathrm{ABC} / \mathrm{M}$, however it has been widely applied also in commercial enterprises, banking, insurance and transport (Král et al., 2010).

Disadvantage of the method is the extent and complexity of ascertaining input data. Also costs for $\mathrm{ABC} / \mathrm{M}$ implementation are considerable, mainly when external consultants are employed. These are the most common reasons for rejecting the $\mathrm{ABC} / \mathrm{M}$ implementation. 
However, existing users' experience of $\mathrm{ABC} / \mathrm{M}$ tends to disprove the above reasons for rejection. Krumwiede (1997) found that $89 \% \mathrm{ABC} / \mathrm{M}$ users said that the implementation has been cost effective. Similar results have been reached in the study of Innes et al. (2000).

Positive impact of $\mathrm{ABC} / \mathrm{M}$ on company performance can be testified by its expansion. $\mathrm{ABC} / \mathrm{M}$ is very widespread in the USA, where it was developed. According to the completed research, there is the adoption rate between $21 \%$ and 53\% among large enterprises (Krumwiede, 1997; Ittner et al., 2002; Cagwin and Bouwman, 2002; Hrisak, 1996; Krumwiede and Suessmair, 2007). Many studies about ABC/M have been carried out in Great Britain. The adoption rate in 1999 was 18 \% (Innes et al., 2000), Al-Omiri and Drury (2007) found stagnation about this rate. They found correlation between the level of the system detail expressed by the number of different types of cost drivers and satisfaction with the $\mathrm{ABC} / \mathrm{M}$ system. The more complex system, the greater user's satisfaction. Australian businesses, that use AngloAmerican cost practices, report relatively high adoption rate (52\% - Chenhall and LangfieldSmith, 1998; 78\% - Baird et al., 2004).

In continental European countries the $\mathrm{ABC} / \mathrm{M}$ expansion is lower. The biggest interest in the method is in Scandinavia. Kallunki and Silvola's (2008) research recorded 28\% adoption rate. Already in 1997 Bjornenak (1997) found that $40 \%$ of the largest manufacturing companies in Norway had already implemented $\mathrm{ABC} / \mathrm{M}$ or planned to do so. In line with the theory, Bjornenak confirmed that companies with a large proportion of overheads adopt $\mathrm{ABC} / \mathrm{M}$ more often.

Traditional cost systems of other European countries are more developed than was true for the USA prior to the rise of $\mathrm{ABC} / \mathrm{M}$. This is according Bhimani et al., (2007) the reason why Europe has not taken place in such an expansion wave of $\mathrm{ABC} / \mathrm{M}$ as in Anglo-American environment. Krumwiede and Suessmair $(2007,2008)$ carried out a comparison of the traditional methods of cost accounting in the USA and German-speaking countries, which in terms of managerial accounting is closer to the Czech Republic. They found that American companies use, on average, only few cost centres and cost drivers in contrast to developed and complex German firms, those places more emphasis on cost management systems. German companies are also more satisfied with their cost system than American organizations. The ABC/M adoption rate was $19 \%$ among German companies.

Research by Bhimani et al. (2007) attempted to eliminate the problem of the commensurability of the different research studies. The authors presented an identical questionnaire (translated into the national languages) at the same time to large businesses within Canada, France, Germany, Italy, Japan, USA and Great Britain. The results revealed that the adoption rate in these countries varied significantly. The greatest expansion was in France, where 82\% companies marked themselves for $\mathrm{ABC} / \mathrm{M}$ users. However, as previously pointed Mevellec (1995), the French expanded calculation technique is not ABC/M, it is more similar to the overhead rates method. This extension thus cannot be regarded as corresponding to reality. The greatest expansion is thus in North America and Great Britain, where the adoption rate was between $40 \%$ and $60 \%$. In Germany it was $30 \%$ and in Italy $28 \%$, with the lowest rate in Japan at $17 \%$.

The situation of $\mathrm{ABC} / \mathrm{M}$ in the Czech Republic has not been deeply investigated. Until recently there had only been a few publications in Czech about ABC/M which might familiarise researchers with its methodology (specifically Staněk, 2003; Petřík, 2007; Popesko, 2009). Although university textbooks for managerial accounting mention this methodology, only 
a few pages are dedicated to it. This may explain the relatively low $\mathrm{ABC} / \mathrm{M}$ adoption rates by Czech businesses discovered in earlier research. Academic research was conducted by Popesko in 2004 amongst medium-sized and large industry organizations with 117 returned questionnaires. He found that $43 \%$ of companies knew of the methodology, though only $21 \%$ of these were fully informed about the $\mathrm{ABC} / \mathrm{M}$ system and only $5 \%$ of enterprises used $\mathrm{ABC} / \mathrm{M}$. The author also found that knowledge of methods increases with the size of the organization. Businesses often use consultant agencies for $\mathrm{ABC} / \mathrm{M}$ system design and implementation. Similar research was repeated in 2007 with very suchlike results - an ABC/M adoption rate of $4 \%$ (Popesko and Novák, 2008). In 2007 Matýska and Šiška carried out research focusing on business efficiency, and among 291 businesses they discovered that 22\% used ABC.

Based on the present situation, the aim of this paper is to chart the expansion of $\mathrm{ABC} / \mathrm{M}$ amongst businesses in the Czech Republic and to ascertain how it is utilized.

\section{Methodology of the research}

To reach the objective of the research, wide research sample was chosen. It consisted of companies from all major economy sectors, companies arranged into sections $\mathrm{A}-\mathrm{N}$ and $\mathrm{P}-$ $\mathrm{R}$ according to the CZ-NACE classification, seated in the Czech Republic. All common legal forms of businesses were represented: joint-stock companies, limited liability companies, limited partnerships, public companies, cooperatives and branch plants. Another criterion was the size of the company - medium-sized and large companies with more than 50 employees.

Identifying data and data from financial statements was obtained from the Albertina CZ Gold Edition nationwide company database, which contains information from the register of legal entities in the Czech Republic. From the complete basic sample containing 9110 businesses, 6363 businesses with a valid email address were in 2013 contacted to complete a questionnaire to obtaining internal information about using $\mathrm{ABC} / \mathrm{M}$. Data collection was carried out using a website-based questionnaire. The addressee was management from the economic, finance or controlling departments. Completed questionnaires were returned by 548 companies, which is the selected sample. The rate of return was therefore $8.61 \%$.

There were found minor differencies between basic sample and selected sample. In the selected sample were slightly more represented industrial enterprises and less service firms than in the basic sample, more joint stock companies were represented at the expense of limited liability companies. Larger businesses answered more often. Although there are differences between the two samples, because of the way of the selection of addressed enterprises (all companies from the basic sample with e-mail contact were contacted) and high absolute number of responses obtained, collected responses can be considered as a meaningful sample of Czech medium-sized and large enterprises.

The data acquired from the questionnaires and from the Albertina CZ database was statistically evaluated. An univariate analysis was used for a description of the samples. The statistically significant difference between groups of firms was tested using the t-test, analyses of variance, the median test, the Mann-Whitney $U$ test, the Kolmogorov-Smirnov test and the Kruskal-Wallis test. A Bivariate analysis was carried out using crosstabs procedure. To measure the strength of association between variables there was also calculated the coefficiency values $\eta$ (éta), Cramer's V, Kendall's Tau, Pearson's correlation coefficient R. The values for all the coefficients are available from the author. The level of statistical significance, with regard to the nature of the issue under investigation, was chosen as $\alpha=0.10$. 
When comparing businesses from the various CZ-NACE sections, businesses from section B, I, P and R were not analysed because only a few businesses from these sections responded, which would not provide sufficient explanatory power for the results. When assessing the entire selected sample, businesses from sections B, I, P and R were included in the analysis.

\section{Results}

$A B C / M$ expansion is illustrated by figure 1 : in the selected sample were 548 companies and 120 of them, i. e. $22 \%$, state that they use $\mathrm{ABC} / \mathrm{M}$ and another $9 \%$ considered its implementation. Most companies (60\%) never even contemplated the introduction of ABC/M.

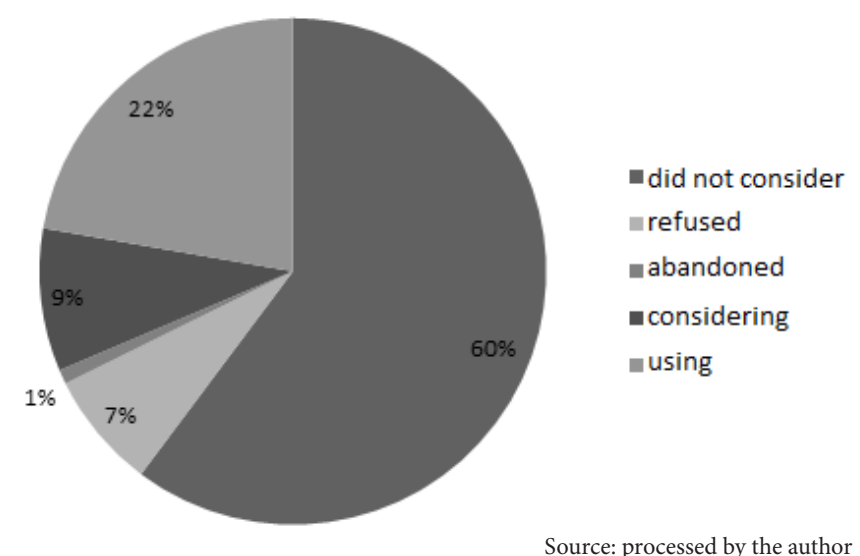

Figure 1: The expansion of $A B C / M$

Regarding of economic sectors, $\mathrm{ABC} / \mathrm{M}$ is most widespread among industrial businesses with mass production (adoption rate 29\%) and service businesses (adoption rate 28\%). Agricultural businesses also used ABC/M frequently, 25\% of them state that they used it. Conversely, the lower penetration is among manufacturing companies with serial and unit production (20\% and 16\%). Even more striking are the differences which can be seen between individual sections of CZ-NACE (figure 2).

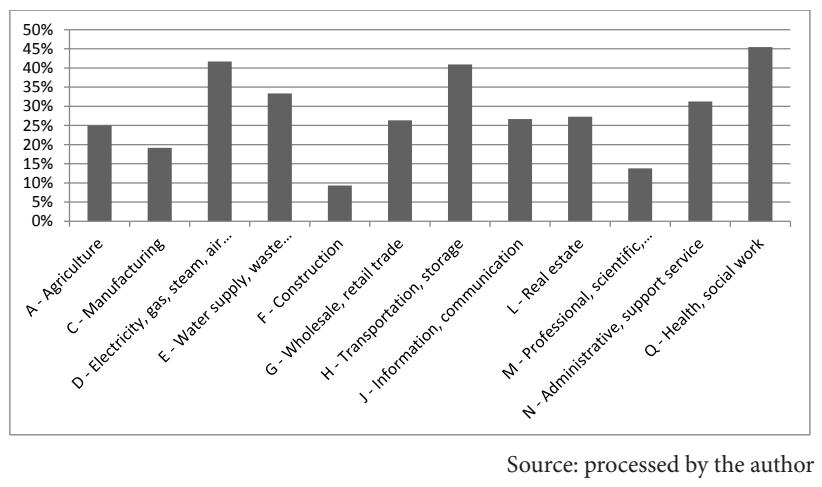

Figure 2: $A B C / M$ acceptance rate, sectors by CZ-NACE 
The graph does not include businesses from sectors from which fewer than ten responses were available, i.e. the sectors of accommodation and catering, financial services, education, art and entertainment. Although the descriptive statistics revealed significant differences between sectors, the relationship between the use of $\mathrm{ABC} / \mathrm{M}$ and the CZ-NACE section is low to moderate and is on the border of statistical significance, with Cramer's $\mathrm{V}=0.239 ; \mathrm{p}=0.106$.

Also the size of the company proved to be medium significant variable for $\mathrm{ABC} / \mathrm{M}$ implementation, larger companies introduced $\mathrm{ABC} / \mathrm{M}$ more frequently (Cramer's $\mathrm{V}=0.239$; $\mathrm{p}=0.001)$ - see tab. 1 .

\begin{tabular}{c|c|c|c|c|c|c|c|c}
\hline $\begin{array}{c}\text { Company size } \\
\text { (employees) }\end{array}$ & $50-99$ & $100-199$ & $200-249$ & $250-499$ & $500-999$ & $\begin{array}{c}1000 \\
-1499\end{array}$ & $\begin{array}{c}1500 \text { and } \\
\text { more }\end{array}$ & Total \\
\hline ABC/M yes & 31 & 40 & 7 & 23 & 12 & 2 & 5 & 120 \\
\hline ABC/M no & 168 & 136 & 35 & 50 & 27 & 5 & 7 & 428 \\
\hline Total & 199 & 176 & 42 & 73 & 39 & 7 & 12 & 548 \\
\hline $\begin{array}{c}\text { Share } \\
\text { in size group }\end{array}$ & $16 \%$ & $23 \%$ & $17 \%$ & $32 \%$ & $31 \%$ & $29 \%$ & $42 \%$ & $22 \%$ \\
\hline
\end{tabular}

Source: processed by the author

\section{Table 1: $A B C / M$ adoption in connection with company size}

Higher adoption rate is among joint-stock companies (29\%) than among limited-liability companies (19\%). No cooperative in the sample used ABC/M. The legal form is statistically significant variable for $\mathrm{ABC} / \mathrm{M}$ adoption. Other legal forms were represented only in single businesses, that is why they were not analysed (Cramer's $\mathrm{V}=0.177 ; \mathrm{p}=0.004$ ).

Businesses with Czech owners predominated in the sample: 413 businesses. The majority owner's country of origin had a moderately strong effect on the adoption of ABC/M (Cramer's $\mathrm{V}=0.263, \mathrm{p}=0.080$ ). Businesses with foreign capital exhibited a markedly higher rate of $\mathrm{ABC} / \mathrm{M}$ adoption than businesses exclusively in Czech hands, where the rate of adoption is $19 \%$. Businesses from all other countries except Germany show an adoption rate between $38 \%$ and $50 \%$ (tab. 2). The only exception is indeed Germany (a total of 46 businesses in the sample) - with these businesses, the adoption rate is only $15 \%$. In the case of businesses with owners from other countries, the adoption of $\mathrm{ABC} / \mathrm{M}$ was not evaluated because of their small representation in the sample.

The percentage amount of overhead costs is linked with $\mathrm{ABC} / \mathrm{M}$ adoption (éta $=0.194$; Cramer's $\mathrm{V}=0.194, \mathrm{p}=0.021$ ). The relationship is indirect, median of enterprises with $\mathrm{ABC} / \mathrm{M}$ is in the category $11-20 \%$, and however median of enterprises without $\mathrm{ABC} / \mathrm{M}$ is in the category $21-30 \%$.

Businesses which refused to introduce $A B C / M$, the most frequently cited as the reason high implementation and maintenance costs and the complexity of the method. After its introduction and use, the method was then abandoned by 5 businesses - the abandonment rate was $4 \%$. One of the reasons given 3 times being the non-utilizability of the information obtained, 2 times the complexity of the method and once for the high costs of implementation and maintenance. 


\begin{tabular}{|c|c|c|c|c|c|c|c|c|c|c|c|}
\hline 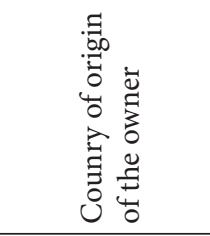 & 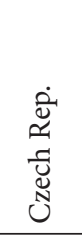 & 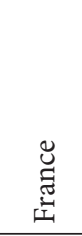 & 䏒 & 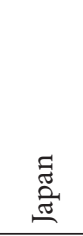 & 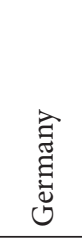 & 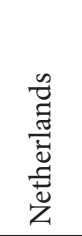 & 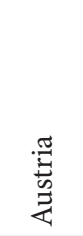 & $\begin{array}{l}\frac{\pi}{3} \\
\text { है } \\
\text { के }\end{array}$ & 岕 & 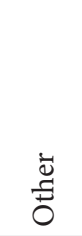 & 苞 \\
\hline $\mathrm{ABC} / \mathrm{M}$ yes ano & 80 & 3 & 2 & 3 & 7 & 5 & 6 & 3 & 3 & 8 & 120 \\
\hline $\mathrm{ABC} / \mathrm{M}$ no & 331 & 3 & 3 & 3 & 39 & 8 & 9 & 5 & 4 & 23 & 428 \\
\hline Total & 411 & 6 & 5 & 6 & 46 & 13 & 15 & 8 & 7 & 31 & 548 \\
\hline $\begin{array}{l}\text { Share in counry } \\
\text { of origin }\end{array}$ & $19 \%$ & $50 \%$ & $40 \%$ & $50 \%$ & $15 \%$ & $38 \%$ & $40 \%$ & $38 \%$ & $43 \%$ & $26 \%$ & $22 \%$ \\
\hline
\end{tabular}

Source: processed by the author

Table 2: Using $A B C / M$ in connection with the country of origin of the majority owner

Although some businesses started to use $A B C / M$ as early as the beginning of the 1990s, it was in the new millennium that a larger-scale increase in the expansion of $\mathrm{ABC} / \mathrm{M}$ came about in the Czech Republic (figure 3).
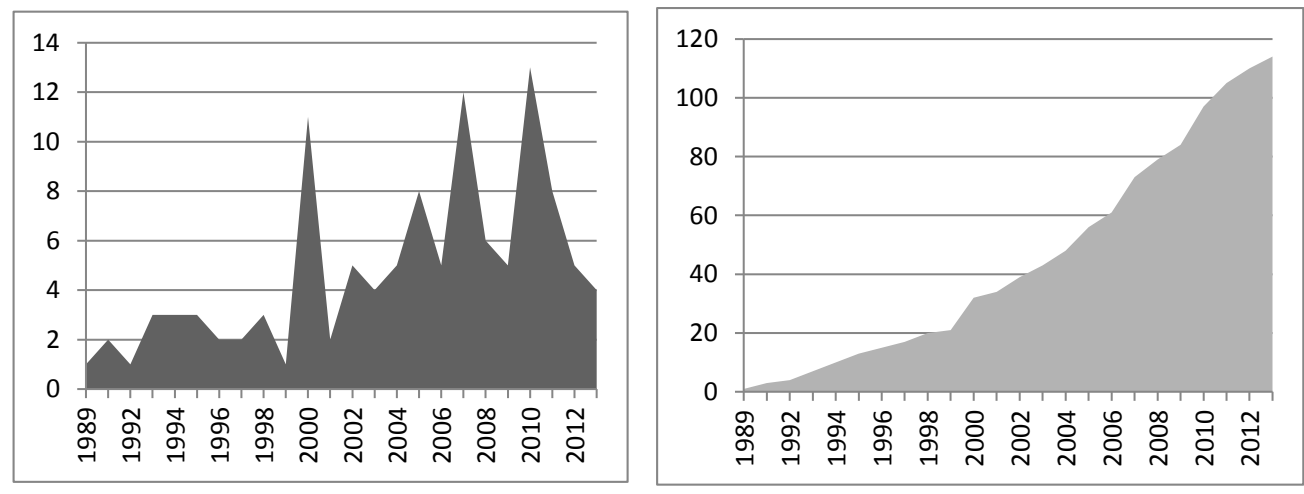

Source: processed by the author

Figure 3: Number of companies that introduced $A B C / M$ in the year; cumulated number of companies that introduced $A B C / M$ in the selected sample 


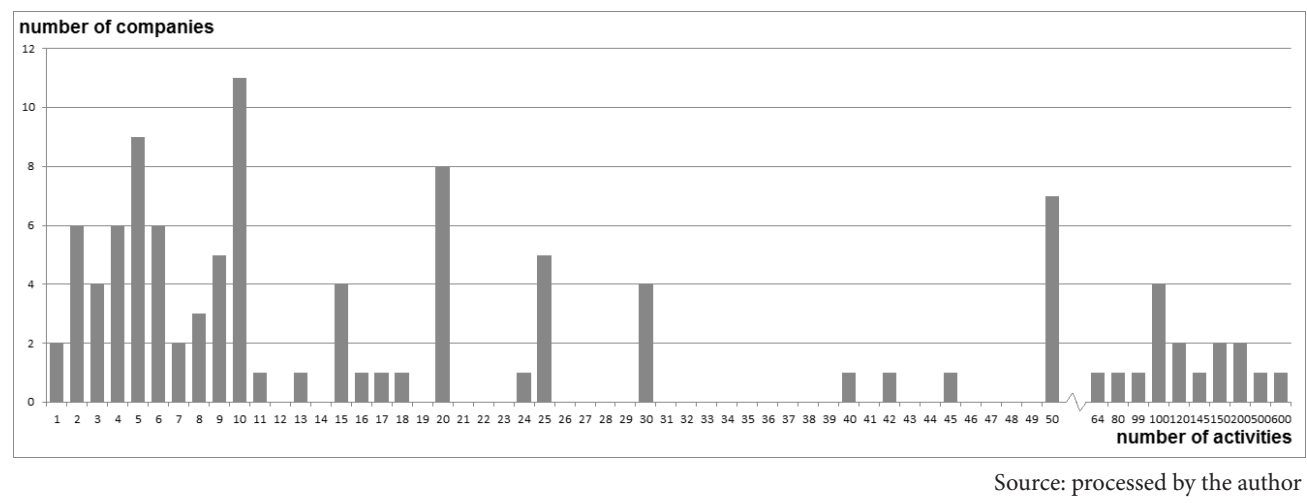

Figure 4: Number of activities used

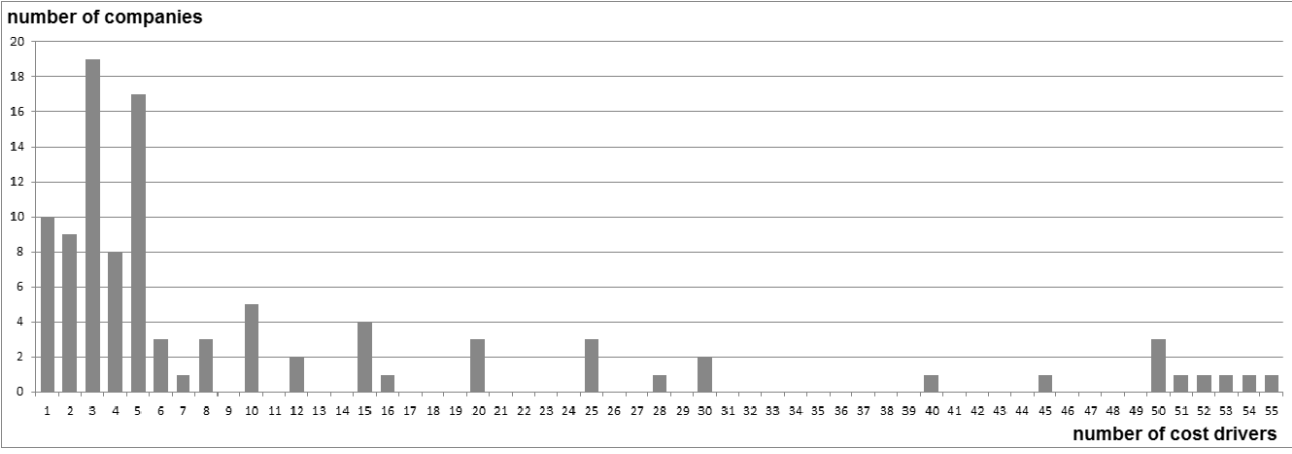

Source: processed by the author

Figure 5: Number of cost drivers used

Two measures were used for measuring the complexity of $A B C / M$ model used in enterprises: number of activities and number of cost drivers. These indicators are strongly correlated (Pearson's $\mathrm{R}=0.693, \mathrm{p}=0.000$ ). The average values of these indicators were 39 and 18 , however, these figures are distorted by outliers. Thus, more informative indicator is the median. Median of used activities is 10, and median of used cost drivers is 5 (figures 4 and 5). These numbers indicate the widespread use of very simple $\mathrm{ABC} / \mathrm{M}$ model. However, there were also firms with a very complicated $\mathrm{ABC} / \mathrm{M}$ model in the sample.

Businesses which abandoned $\mathrm{ABC} / \mathrm{M}$ frequently used the more complicated model. Nevertheless, mutual dependency between the complexity of the $\mathrm{ABC} / \mathrm{M}$ model and the perceived success of the $\mathrm{ABC} / \mathrm{M}$ implementation is also statistically significant (Kendal' Tau for number of activities $=-0.005 ; \mathrm{p}=0.949$; Kendal' Tau for number of cost drivers $=0.077 ; \mathrm{p}=0.361$ ).

Field of business significantly affects the complexity of the model only in case of cost drivers (Cramer's $\mathrm{V}=0.536 ; \mathrm{p}=0.002$ ). A higher number of cost drivers is used mainly in the manufacturing industry. The association between the complexity of the model and the number of activities were not detected (Cramer`s V $=0.514 ; \mathrm{p}=0.979$ ). 
The extent of utilizing information from $A B C / M$ was also examined. Among corporate processes $\mathrm{ABC} / \mathrm{M}$ was employed most with the process of production (88 times), then sales (73 times), purchasing (57 times), administration (55 times), service and auxiliary processes (52 times), distribution and storage (51 times), human resources (43 times), inspection (41 times), with the lowest figure for development (34 times) and marketing (32 times). Most businesses employ $\mathrm{ABC} / \mathrm{M}$ only for some processes, not for managing the costs of all the business's processes. If $\mathrm{ABC} / \mathrm{M}$ is utilized only for one process, then it is usually production. $43 \%$ of businesses employ $\mathrm{ABC} / \mathrm{M}$ for a maximum of 3 processes, and $68 \%$ of businesses for a maximum of 5 processes.

In terms of the purpose of utilization, $\mathrm{ABC} / \mathrm{M}$ is most often used to determine the costs of products, set prices, budgets and identify the costs of activities (tab. 3).

\begin{tabular}{l|c|l|c}
\hline Utilization & $\begin{array}{c}\text { Number } \\
\text { of firms }\end{array}$ & Utilization & $\begin{array}{c}\text { Number } \\
\text { of firms }\end{array}$ \\
\hline Determining the costs of products & 99 & Investment evaluation & 33 \\
\hline Pricing & 88 & Design of new products & 28 \\
\hline Budgeting & 76 & $\begin{array}{l}\text { Identification of unused } \\
\text { capacity costs }\end{array}$ & 24 \\
\hline Identification of activity costs & 74 & Benchmarking & 24 \\
\hline Customer profitability analysis & 65 & $\begin{array}{l}\text { Reengineering } \\
\text { and process improvement }\end{array}$ & 23 \\
\hline $\begin{array}{l}\text { Measuring performance } \\
\text { of activities }\end{array}$ & 61 & Decision making about outsourcing & 23 \\
\hline Costs modelling & 60 & $\begin{array}{l}\text { Decision making about } \\
\text { production volume }\end{array}$ & 14 \\
\hline $\begin{array}{l}\text { Identification } \\
\text { of administrative costs }\end{array}$ & 59 & $\begin{array}{l}\text { Decision making about } \\
\text { production mix }\end{array}$ & 6 \\
\hline $\begin{array}{l}\text { Identification of cost drivers } \\
\text { Detecting costs of quality }\end{array}$ & 56 & Other & \\
\hline
\end{tabular}

\section{Table 3: Purpose of $A B C / M$ utilization}

The use of $A B C / M$ together with other strategic management tools was examined. Results show that these tools are widely used among Czech companies (figure 6). At last one tool out of ten selected is used by $64 \%$ of businesses. 


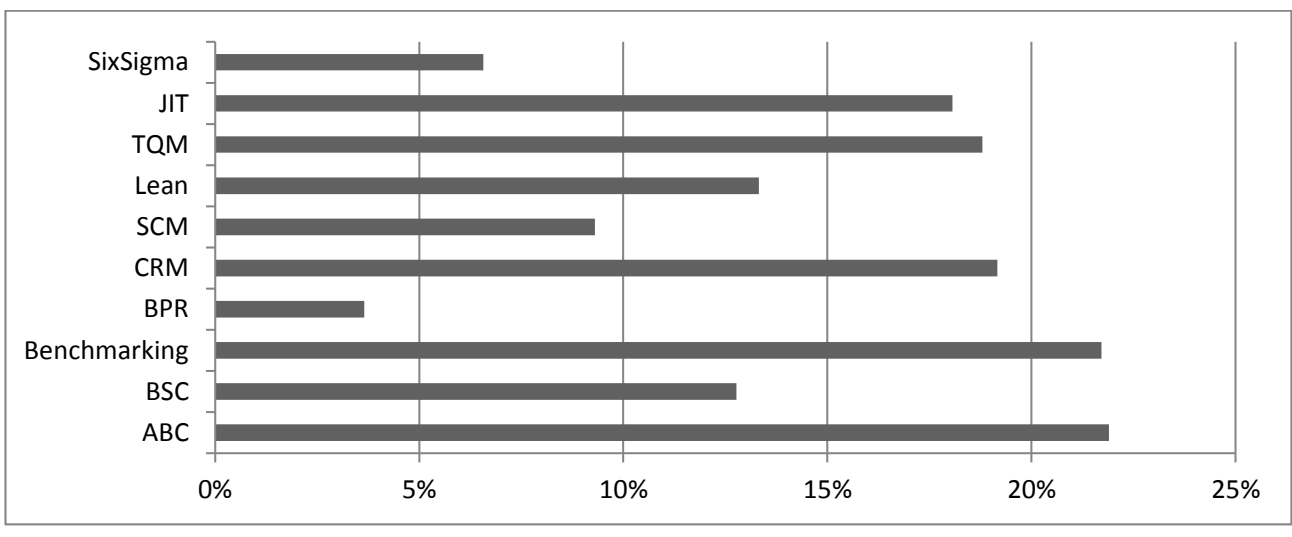

Source: Pokorná 2014

Figure 6: Extension of strategic management tools in Czech enterprises

Like the association between the use of $\mathrm{ABC} / \mathrm{M}$ and size of business, other tools are also used significantly more often in larger enterprises. Industry, legal form and country of origin of the majority owner are also significant variables in adoption of other strategic management tool (more about extension of strategic management tools in Czech Republic in Pokorná, 2014).

The strategic tools are significantly and positively broadly associated with each other. Firms that adopt one instrument are likely to employ other instruments. $\mathrm{ABC} / \mathrm{M}$ was most often used together with Balanced Scorecard and Benchmarking, even though their mutual relationship is not particularly close (table 4 ).

\begin{tabular}{c|c|c|c|c|c|c|c|c|c|c}
\hline \multicolumn{2}{l|}{} & BSC & $\begin{array}{c}\text { Bench- } \\
\text { marking }\end{array}$ & BPR & CRM & SCM & Lean & TQM & JIT & SixSigma \\
\hline \multirow{2}{*}{$\mathrm{ABC} / \mathrm{M}$} & Cramér`s V & .126 & .127 & .114 & .064 & .079 & .085 & -.023 & .081 & .006 \\
\cline { 2 - 11 } & Sig. & .003 & .003 & .008 & .138 & .066 & .049 & .595 & .062 & .895 \\
\hline
\end{tabular}

Source: processed by the author

Table 4: Association rate of using $\mathrm{ABC} / \mathrm{M}$ and other strategic management tools

The $A B C / M$ implementation is positively valued by three quarters of the respondents (figure 7). The worst evaluation of "very unsuccessful" was not selected even once. Even companies that abandoned $\mathrm{ABC} / \mathrm{M}$ (only 5 businesses in the sample) evaluated its adoption twice as neutral and three times as rather unsuccessful. 


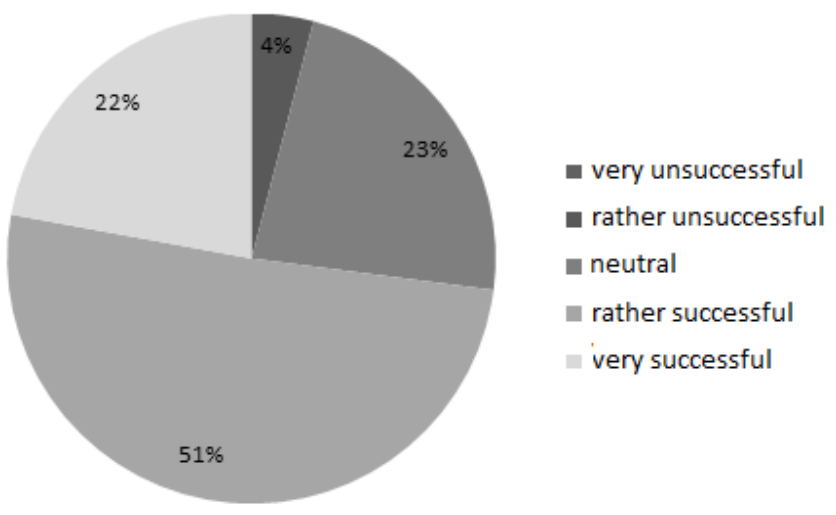

Source: processed by the author

\section{Figure 7: Success of $A B C / M$ introduction from the perspective of respondents}

\section{Discussion}

The $\mathrm{ABC} / \mathrm{M}$ expansion among Czech enterprises in the new millennium gradually increased. The current situation is such that the adoption rate is slightly lower than in developed English-speaking countries. When compared with recent studies in non-English-speaking European countries (Majerová, 2010), which we are in terms of cost systems closer than AngloAmerican systems, ABC/M's acceptance rate in the Czech Republic is at an average level. The potential for further spread of the $\mathrm{ABC} / \mathrm{M}$ is still not exhausted because $60 \%$ of companies still had not even considered its adoption. Companies, that considered $\mathrm{ABC} / \mathrm{M}$ adoption and rejected it, cited the anticipated implementation costs and complexity of this tool as the reason. The same reasons were also mentioned in earlier studies (Hicks, 1997; Kaplan and Anderson, 2004). Lack of information about the tool as a reason for rejection is no longer so much represented as in the study of Popesko (2004).

Expansion differs in various economic sectors. Relatively high adoption rate is surprisingly among agricultural businesses, which generally adopt strategic management tools to a lesser degree (Suchánek et al., 2013). The lower expansion among construction businesses in the Czech environment until recent times can be explained by lower pressure on prices in this sector (Odehnalová and Pirožek, 2014) and by the specific type of production, in which every building is different. In contrast, a high percentage of adoption was ascertained in health care, in which organizations are forced to establish a realistic price for health-care outputs in order to be covered by health insurance. Some foreign studies also mention the high level of expansion in health care (Yereli, 2009; Upda, 1996).

Other variables that affect the $\mathrm{ABC} / \mathrm{M}$ adoption are the organization size and legal forms. Large companies have more resources and knowledge for such projects. The same applies to joint-stock companies, which are generally larger. 
Theory says that the $\mathrm{ABC} / \mathrm{M}$ brings greater benefits for companies with higher overheads (Cooper and Kaplan, 1990; Krumwiede, 1998; Cagwin and Bouwman, 2002; King et al., 2010). The empirical results paradoxically show that $\mathrm{ABC} / \mathrm{M}$ is used more in companies with lower level of overheads.

The higher adoption rate of $\mathrm{ABC} / \mathrm{M}$ in businesses with foreign owners can be explained by the fact that there isn't such a large language barrier among foreign owners and in multinational companies compared to national business entities, which means that their employees can quickly adopt new concepts and innovation in areas including cost management from professional literature mainly written in English. Here a role is also played by the fact that some businesses with foreign owners operating in the Czech Republic came into being through the takeover by a foreign company, which must have shown a significant degree of success in the original market to have made it into another market too. Companies like this are probably more innovative. In addition, in many cases the owners are predominantly from developed western countries, which were confirmed in earlier studies to have a higher rate of adoption of ABC/M (Bhimani et al., 2007).

In the Czech Republic, there is the most common form of $\mathrm{ABC} / \mathrm{M}$ a simple model with few activities and cost drivers. The system is often used only for key or costly processes. It is a compromise between the accuracy of the information obtained and the lack of finances, when company want to implement $\mathrm{ABC} / \mathrm{M}$. Such a reduced model offers only limited use of $\mathrm{ABC} / \mathrm{M}$ information, like identification of product costs and activities costs, more complex analysis is not possible. On the other hand, in this sample there were also businesses with very complex $\mathrm{ABC} / \mathrm{M}$ systems, with the number of activities in the hundreds. Reported uses of $\mathrm{ABC} / \mathrm{M}$ information are also very wide. In favour of a comprehensive model speaks the research by Al-Omiry and Drury (1997), who found a significant correlation between satisfaction with the $\mathrm{ABC} / \mathrm{M}$ system and its complexity. This conclusion, however, on Czech data was not confirmed - a more complex model does not lead to greater satisfaction with ABC/M system or increase in financial performance of the company (Pokorná, 2014), but it almost certainly entails higher implementation and maintenance.

In accordance with the theory and similar foreign empirical studies (Cagwin and Barker, 2006; Maiga and Jacobs, 2006; Krumwiede and Charles, 2011; Mijoč et al., 2014, and others), the association between the use of $\mathrm{ABC} / \mathrm{M}$ and other strategic management tools was confirmed. Enterprises using one tool more likely introduce another.

Just like in the study by Krumwiede and Charles (2011), the perceived success of the ABC/M introduction is evaluated very positively by the enterprise's managers. $\mathrm{ABC} / \mathrm{M}$ also demonstrates the usefulness of the low abandonment rate, comparable with France, Great Britain, Canada and the USA (Bhimani et al., 2007).

\section{Conclusion}

In the context of the increasing intensity of competition in recent decades, rigorous cost management became an important part of the management of many enterprises. The concept of process management also penetrates to the managing costs and the activity-based costing/ management is increasingly gaining access among companies worldwide.

In the Czech Republic the expansion and the level of using of ABC/M has not been studied on a sufficiently comprehensive sample. The aim of this article was to fill these white places. 
To reach this, own extensive quantitative research was carried out. The quantitative survey was conducted using a questionnaire and the data from the Albertina database. Thanks to the high absolute number of returned questionnaires, the obtained results can be generalized to a great extent to the population of medium-sized and large Czech enterprises.

It was found that Czech companies began to introduce $\mathrm{ABC} / \mathrm{M}$ with increasing intensity especially after the turn of the millennium and now the extension is almost comparable to the western countries. The growing expansion can be explained by the gradual placement of information about $\mathrm{ABC} / \mathrm{M}$ in courses at Czech universities and the availability of professional and popular literature including the issue of $\mathrm{ABC} / \mathrm{M}$ in Czech language.

Besides the growing expansion, also low abandonment rate testifies to the success of the $\mathrm{ABC} / \mathrm{M}$ introduction. On the other hand, more than half of the companies not even consider the implementation. The main reasons are estimated costs and the complexity of this tool.

$\mathrm{ABC} / \mathrm{M}$ is the most prevalent among industrial companies with mass production and service businesses, although the theory talks about the highest benefit for companies with serial production. As expected, $\mathrm{ABC} / \mathrm{M}$ is more used in large enterprises with sufficient funds for projects of this type and in terms of legal form, especially for joint stock companies. Higher acceptance rate is generally in enterprises with foreign capital.

The survey brought information that Czech companies use mostly simple ABC/M model with a small number of activities and cost drivers. Low rate of use of the possibilities offered by the developed $\mathrm{ABC} / \mathrm{M}$ model is probably linked to this. In such a model, a deeper activity analysis is available and carried out only for key enterprise processes, especially the production. However, it was found that the complexity of the model used is not linked to success of the $\mathrm{ABC}$ adoption, subjectively perceived by company managers.

Besides $\mathrm{ABC} / \mathrm{M}$ also other strategic management tools are relatively widely expanded, although the use of their potential synergic effect was not found.

Based on current development and foreign experiences, additional expansion of $\mathrm{ABC} / \mathrm{M}$ among Czech companies is expected. Thanks to the increasing awareness of this tool and its possibilities, increasing extent of its use in the Czech Republic is also assumed.

\section{Acknowledgement}

This article is a partial output of the specific research project of Masaryk University entitled: "Quality management and company competitiveness" (number 0799/2013).

\section{References}

AL-KHADASH, H. A. and FERIDUN, M. (2006) Impact of strategic initiatives in management accounting on corporate financial performance: evidence from Amman Stock Exchange, Managing global transitions, 4, 4, pp. 299-312.

AL-OMIRI, M. and DRURY, C. (2007) A survey of factors influencing the choice of product costing systems in UK organizations. Management accounting research. pp. 399-424.

AYEDH, A., and EDDINE, H., (2015). The impact of advance management accounting techniques on performance: The case of Malaysia. Middle East Journal of Business, 10, 2

BAIRD, K. M., HARRISON, G. L. and REEVE, R. C. (2004) Adoption of activity management practices: a note on the extent of adoption and the influence of organizational and cultural factors, Management accounting research, 15, pp. 384-399. 
BANKER, R. D., BARDHAN, I. R. and CHEN, T. (2008) The role of manufacturing practices in mediating the impact of $\mathrm{ABC}$ on plant performance. Accounting, Organizations and Society. 33, pp. 1-19.

BHIMANI, A. et al. (2007) Activity-Based costing: how far have we come internationally? Cost management. May/June; 21, 3. pg. 12.

BJORNENAK, T. (1997) Diffusion and accounting: the case of ABC in Norway. Management accounting research. 8, pp 3-17.

CAGWIN, D. and BARKER, K.J. (2006) Activity-based costing, total quality management and business process reengineering: their separate and concurrent association with improvement in financial performance. Academy of accounting and financial studies journal, 10, 1.

CAGWIN, D. and BOUWMAN, M.J. (2002) The association between activity-based costing and improvement in financial performance. Management accounting research, 13, pp. 1-39.

CAM-I (Consortium for Advanced Management International) (2000) Glossary of activity-based management. ver, 3.0. Wiley Publishing.

CHENHALL, R.H. and LANGFIELD-SMITH, K., (1998). Adoption and benefits of management accounting practices: an Australian study. Management accounting research. 9 (1), pp. 1-19.

COHEN, S. et al. (2005) ABC: adopters, supporters, deniers and unawares. Managerial auditing journal, 20, 8/9. pg. 981.

COKINS, G. (2001) Activity-Based Cost Management: An executive's guide. USA, John Wiley \& Sons.

COOPER, R. and KAPLAN, R.S. (1990) Measure costs right: make the right decision. The CPA Journal; Feb; 60, 2. pg. 38.

HARDAN, A. S, SHATNAWI, T. M. (2013) Impact of applying the ABC on improving the financial performance in telecom companies. International Journal of Business and Management, 8, 48-61

HICKS, D. T. (1997) Impediments to adopting ABC at smaller organizations. Cost Management Update, April, vol. 74, p. 1-3

HRISAK, D., (1996) The controller as business strategist. Management accounting 78 (6), pp. 48-49 In Baird, K.M., Harrison, G.L. and Reeve, R.C. (2004) Adoption of activity management practices: a note on the extent of adoption and the influence of organizational and cultural factors, Management accounting research, 15, pp. 384-399.

INNES, J., MITCHEL, F. and SINCLAIR, D. (2000) Activity-based costing in the U.K.s largest companies: a comparison of 1994 and 1999 survey results. Management accounting research., 11, pp. 349-362.

ITTNER, C. D., LANEN, W. N. and LARCKER, D. F., (2002) The association between activity-based costing and manufacturing performance. Journal of accounting research, 40, 3, pp. 711-726.

KALLUNKI, J.P. and SILVOLA, H: (2008) The effect of organizational life cycle stage on the use of activity-based costing. Management accounting research. 19, pp. 62-79.

KAPLAN, R. S., ANDERSON, S. R. (2004) Time-driven Activity-Based costing. Harvard Business Review. Nov. $8 \mathrm{p}$

KENNEDY, T. and AFFLECK-GRAVES, J. (2001) The impact of activity-based costing techniques on firm performance, Journal of management accounting research, 13, pp. 19-45.

KRÁL, B. et al. (2010) Managerial Accounting. 3rd edition. Praha: Management Press, 660 p.

KRUMWIEDE, K. (1997) ABC adoption hits new high, but is ABC worth implementation costs? Cost management update, Jan; 71. Pg. 1.

KRUMWIEDE, K.R. (1998) ABC why it's tried and how it succeeds. Management accounting, Apr; 79, 10. Pg. 32.

KRUMWIEDE, K. R. and CHARLES, S. L. (2011) The use of activity-based costing with competitive strategies: impact on firm performance. Engage to make a difference, American Accounting Association - anual meeting, 6-10 August. Denver.

KRUMWIEDE, K. R. and SUESSMAIR, A. (2007) Comparing U.S. and German cost accounting methods. Management accounting quarterly. Spring 8, 3 . 
KRUMWIEDE, K.R. and SUESSMAIR, A. (2008) A closer look at German cost accounting methods. Management accounting quarterly. Fall; 10, 1.

MAIGA, A.S. and JACOBS, F.A. (2006) Assessing the impact of benchmarking antecedents on quality improvement and its financial consequences, Journal of management accounting research, Vol. 18, pp. 97-123.

MAJEROVÁ, J. (2010) The international spread of activity-based costing. Through crisis reflection to performance enhancement. Prague, pp. 161-170.

MATÝSKA, M., ŠIŠKA, L. (2007) Řízení a měření výkonnosti podniků. Masarykova univerzita, $98 \mathrm{~s}$. Report with the results of the survey

MÉVELLEC, P. (1995) The French Approach to ABC. Australian Accountant. 65, 3, p. 10

MIJOČ, J., STARČEVIC, D.P. and MIJOČ, I. (2014) Investigation of the relationship between contemporary cost management method and improvement in financial performance. Economic Research-Ekonomska Istraživanja. 27, 1, p. 393-413

ODEHNALOVÁ, P. and PIROŽEK, P. (2014) Innovations and entrepreneurship at a time of financial crisis in Czech and Austrian construction industries. Proceedings of the 9th European conference on innovation and entrepreneurship (ECIE). Dr Brendan Galbraith, University of Ulster Belfast, UK. pp. 355-360.

PETŘÍK, T. (2007) Procesní a hodnotové rízení firem a organizací - nákladová technika a komplexní manažerská metoda ABC/ABM. Praha : Linde, 911 s. ISBN: 978-80-7201-648-8

POKORNÁ, J. (2014) Which strategic initiatives are associated with higher corporate financial performance? Case of the Czech Republic. International Journal of Business and Management Studies, USA: UniversityPublications.net. Vol. 3, no. 1, pp. 231-239.

POPESKO, B. (2004) Application of process cost management in terms of Czech organizations. Univerzita Tomáše Bati ve Zlíně, Dissertation thesis.

POPESKO, B. (2009) Moderní metody řizení nákladi̊: Jak dosáhnout efektivního vynakládání nákladi̊ a jejich snižení. Praha : Grada. 240 s. ISBN 978-80-247-2974-9

POPESKO, B. and NOVÁK, P. (2008) Activity-based costing aplications in the Czech Republic. Lex et scientia international journal, 15, 1, Nicolaue Tulescu University, Bucharest.

RYBKA, Z. (2003) Principles of the Bata Management System. In Bata: vzdělávací CD-ROM o Tomáši Batovi [CD-ROM]. Marada Capital Services

STANĚK, V. (2003) Performance improvement by process cost management. Praha: Grada, 2003. 236 pages.

SUCHÁNEK, P. et al. (2013) Effect of the quality on the company performance and competitiveness. Brno: Masarykova univerzita. 147 pages.

UPDA, S. (1996) Activity-based costing for hospitals. Health care management review. 21(3), pp. 83-96 YERELI, A.N. (2009) Activity-based costing and its application in a Turkish university hospital. AORN Journal, March, 89, 3. pp. 573-591.

Jana Pokorná jana.pokorna@mail.muni.cz

Masaryk University

Faculty of Economics and Administration 